\title{
Response to 'Protective parasites and medicinal microbes? The case for the hygiene hypothesis' by C. Gore and A. Custovic
}

\author{
C.P. van Schayck*
}

Department of General Practice, Care and Public Health Research Institute, University of Maastricht, P.O. Box 616, Maastricht 6200, The Netherlands

I would like to thank Dr. Gore and Prof. Custovic for their excellent overview [1] of the literature as well as for making it very simple for me to dispute their main conclusion: "There is ample evidence to support the hygiene hypothesis"'. They clearly showed that the Th2/Th1 paradigm does not support the hygiene hypothesis. Moreover, they showed that the evidence of a protective effect of both viral colds and measles infections is inconclusive. They showed that there are at least as many studies pointing to an increased risk of sensitisation to inhaled allergens if exposed to high levels of endotoxins than the (more) often cited opposite effect. We have shown in a previous study that there is a doseresponse relationship between endotoxins exposure and the yearly decline in lung function in pig farmers [2].

The only strong argument in favor of the hygiene hypothesis thus far is the fact that colonization of the gastro intestinal tract by bacteria seems to be a pre-requisite for an immune response, especially the placebo-controlled trials of Kalliomaki et al. $[3,4]$ demonstrating that lactobacilli may improve or even prevent atopic dermatitis and food allergy is a convincing argument.
So in conclusion, I agree with everything Dr. Gore and Prof. Custovic put forward with the exception of their conclusion. Their paper shows that there is inconclusive evidence for the hygiene hypothesis. We need targe, well-designed randomised controlled intervention trials in order to investigate this. Moreover, we need to redefine the term hygiene hypothesis, which is too non-specific and too sensational for the lay press.

\section{References}

[1] Gore C, Custovic A. Protective parasites and medicinal microbes? The case for the hygiene hypothesis. Primary Care Resp J 2004;13(2):68-75.

[2] Vogelzang PFJ, van der Gulden JWJ, Folgering H, Kok JJ, Heederik D, Preller L, et al. Endotoxin exposure as a major determinant of lung function decline in pig farmers. Am J Respir Crit Care Med 1998;157(1):15-8.

[3] Kalliomaki M, Salminen S, Arvilommi H, Kero P, Koskinen $\mathrm{P}$, Isolauri $\mathrm{E}$. Probiotics in primary prevention of atopic disease: a randomized placebo-controlled trial. Lancet 2001;357(9262):1076-9.

[4] Kalliomaki M, Salminen S, Poussa T, Arvilommi H, Isolauri E. Probiotics in the management of atopic eczema. Clin Exp Allergy 2000;30(11):1604-10.

\section{Available online at www.sciencedirect.com \\ Available online at atpil/awaw.thepcrj.com}

\footnotetext{
*Tel.: +31-43-3882152; fax: +31-43-3884225.

E-mail address: O.vanSchayck@caphri.unimaas.nl (C.P. van Schayck).
}

1471-4418/\$30.00 ๔ 2004 General Practice Airways Group. Published by Elsevier Ltd. All rights reserved. 